toutes les races d'A.É.F., les tribunaux coutumiers sont souvent appelés à régler des litiges qui opposent des personnes régies par des coutumes parfois peu connues de leurs assesseurs. C'est pourquoi le Conseil Coutumier a essayé de donner un instrument de travail aux tribuns indigènes de Brazzaville en leur permettant de se référer à des coutumes écrites en ce qui concerne les principales races du Moyen-Congo. On espère que cette initiative du Conseil Coutumier s'étendra dans les autres territoires de la Fedération et que des filiales seront créées à d'autres centres. Le Conseil Coutumier doit en outre servir d'organisme central consultatif pour les juridictions indigènes. Les cas pour lesquels la coutume n'est pas nette ou ceux dans lesquels il y a opposition de coutumes lui seront soumis.

Un fascicule, édité par le Conseil Coutumier, contient un exposé des coutumes du MoyenCongo, publié sous la responsabilité des notables africains de Poto-poto et de Bacongo, dont la liste est imprimée.

Les sections du fascicule comprennent des chapitres traitant de la famille: les droits et les devoirs du chef de famille; le mariage; les fiançailles; régime patriarcal, régime matriarcal; la dot; situation des époux; dissolution du mariage. Un chapitre traite des coutumes sangha - sangha, bakouele et djem - celles-ci étant assez différentes des autres du MoyenCongo. Deux chapitres sont consacrés aux coutumes concernant la naissance et le choix de nom. En conclusion, le Conseil Coutumier formule quelques recommandations concernant le divorce.

\title{
Interafrican Soils Conference
}

THE Interafrican Soils Conference held at Léopoldville in 1954 (see Africa, Oct. 1954, p. 272) reviewed the progress made by the permanent organizations founded in 1948 (Bureau Interafricain des sols, Paris; Service pédologique africain, Yangambi, and three regional committees). In approving the work done by these organizations, under the auspices of C.C.T.A., the conference took special note of the results achieved in the fields of study, cartography, soil conservation and utilization. It recommended that details of the methods of soil analysis used by the member countries should be communicated to S.P.A. at Yangambi, and emphasized the importance of studying the composition, origins, and formation of soils, and the bearing of these studies on measures for conserving soil fertility. Considerable discussion took place on the project of preparing a series of maps of soils in different regions, and on the need for a standardization of terminology, nomenclature, and methods of cartography. Reports were presented and discussed on means of conserving soils, maintaining fertility and preventing deterioration. These reports revealed that substantial progress had been made in a number of territories in preventing erosion and sterilization, but the conference agreed that additional measures were necessary, particularly in the direction of educating rural populations and arousing their interest. Overstocking was also one of the problems discussed. The need for greater knowledge of, and better co-ordination of existing information relating to, the different systems of agriculture, was emphasized. A particular point was made of the importance of testing and supplementing laboratory methods, especially as regards fertilizers-both animal and mineral, by a thorough knowledge of the different soils and plants of Africa.

\section{The Killie Campbell Africana Collection}

SCHOLARS and students visiting or working in South Africa should miss no opportunity, when in Durban, of seeing Miss Killie Campbell's magnificent collection of Africana. At present kept in the old family house of the Cape Dutch style--220 Marriott Road, Durban (given to the city of Durban by Mr. William Campbell)-it is eventually intended to transfer 